\title{
Political Implications of Turkey - Qatar Gas Pipeline Construction on European Union Energy Security
}

\section{Ariscynatha Putra Ingpraja}

\author{
Ariscynatha Putra Ingpraja \\ Affiliation : Universitas Pertamina \\ City : Jakarta \\ Country : Indonesia \\ Email \\ arisputra.ingpraja@gmail.com

\section{History} \\ Submission : 14 May 2020 \\ Review : 20 June 2020 \\ Completed \\ Accepted : 22 June 2020 \\ Available : 30 June 2020 \\ Online \\ DOI : \\ 10.51413/jisea.Vol1.Iss1.2020.43 - 61

\section{Copyright} \\ This is an open access article distributed \\ under the term of the creative commons \\ attribution 4.0 international licence
}

\begin{abstract}
This paper will discuss the political implication caused by Turkey-Qatar Gas Pipeline to the European Union energy security. The development of a logistics facility in this program could be a double-edged sword for the European Union member. Using realism as the leading theory that emphasizes politics as the main power to gain the state's national interest, writers try to build analytical case studies. With its hold of the logistics facility, Turkey could control the distribution of natural gas exporting to Europe. European Union members need to import natural gas to strengthen the energy security sector of their lack of energy sources. Through the dependency energy sources created by both actor, this will affect the European Union energy security, notably, by the facility owner's state.
\end{abstract}

Key Words: Politics Implication, Qatar-Turkey Gas Pipeline, Energy Security

\section{Cite this article :}

Ingpraja, A. P. (2020). Political Implications of Turkey

- Qatar Gas Pipeline Construction on European Union Energy Security. Journal of International Studies on Energy Affairs, 1(1), 43-61. https://doi.org/10.51413/jisea.Vol1.Iss1.2020.43 - 61

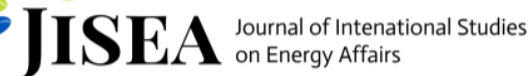




\section{INTRODUCTION}

The crisis that occurred in Ukraine, which also involved Russia regarding the annexation of Crimea, became an incident that reminded the European Union to reduce its dependence on natural gas supplies from Russia. Energy experts predict that in the next decade, the energy market in European Union member states will increase due to increasing energy needs. Another cause is the increase in prices where there is a plan to increase the tariff for carbon fuels (CO2) at US \$ 25 and US \$ 30-40 per tonne in 2025 (Rosendahl, 2018). The European Union's concern about instability involving Russia has recognized and responded to since 2000. This response marked by the release of a Green Paper by the European Commission, which discusses plans to reduce the dependence on imports of natural gas from Russia. Also, in 2004 this response was increasingly evident with the adoption of a Directive Document with the primary objective of "ensuring an adequate level for the security of gas supply, in particular in the event of a major supply disruption" and "ensuring an adequate level for the security of gas supply, in particular in the event of a major supply disruption." These two goals are strong evidence of the EU's desire to reduce dependence on Russia, which within a decade has had three conflicts with neighboring countries such as Ukraine and Georgia, thus affecting regional stability in Europe.

According to Eurostat data in 2016, the percentage of Russian natural gas supplies to the European Union was $39.9 \%$ of the total EU gas imports. This number has increased by $2.3 \%$ from 2015. This figure places Russia as the largest exporter of natural gas commodities to the European Union, only one rank different from Norway, which supplies 24.8\%. The large percentage of imports consider having positioned EU member states in a vulnerable position in energy security if one day there is instability or a conflict involving Russia, especially in Ukraine. The conflict that occurred in Ukraine since 2014 has become necessary because Ukraine, which lost the Crimea Province after being annexed by Russia through the occupation and establishment of the Republic of 
Crimea, is a transit country in the natural gas distribution channel to the European Union. The existence of the Soyuz and Brotherhood natural gas pipelines lead to the Transgas pipeline with the main terminal in Plavecky Peter, Slovakia. This gas pipeline with Ukraine as a transit point to Europe in 2018 has distributed $116 \mathrm{bcm}$ of natural gas (Pirani and Roland, 2018).

Qatar has not played an essential role in energy policy in Europe, especially in the European Union. However, Qatar sees bright market prospects with this critical momentum to increase natural gas consumers and foreign exchange earnings. The diplomatic crisis between Qatar and Gulf countries such as Saudi Arabia, the United Arab Emirates, and Bahrain also involved Egypt. The diplomatic crisis that led to an embargo on export-import activities to and from Qatar caused this country to lose its income source. The accusation that Qatar supports the funding of terrorism activities in the Middle East and the ownership of good relations with Iran to the point of interfering in the internal politics of the Persian state is the leading cause (Al Jazeera, 2017). According to data from the British Petroleum Company in the BP Statistical Review of World Energy (2018), Qatar has a natural gas production capacity of $175.7 \mathrm{bcm}$ or $4.8 \%$ of the world's total natural gas production and proven reserves of $24.9 \mathrm{tcm}$ or $12.9 \%$ of the world's total natural gas reserves. Qatar's gas exports have not competed in the European market because the price was too high due to logistical costs via tankers, which was expensive and at high risk due to conflict-prone routes. Building a natural gas pipeline installation to Turkey as a transit gate is considered a solution to save logistics costs. With reduced logistics costs, Qatar's natural gas will compete with comparable commodities supplied by Russia to Europe.

The existence of a market in Europe and a supplier of Qatar resources is seen as an opportunity by Turkey to gain material and non-material profits. With the construction of the Qatar - Turkey natural gas pipeline, the country led by President Erdogan will get a transit fee and other energy fee benefits (Chang, 2015). Turkey, which is strategically between the continents of Europe and Asia, has long been a transit for 
other commodities so that it holds the title as the gateway to the two continents. As with other countries, Turkey has relations with European countries, especially those of the European Union. Both Turkey and the European Union view each other that their relationship is vital to achieving their national interests. In other words, Turkey and the European Union share influence in the global world order. Since 1987, Turkey has submitted its application to join the European Economic Community (ECC), the European Union's forerunner. However, until now, with the existing dynamics, Turkey has not fulfilled the EU membership requirements requested through the European Council. Still talking about the transit gate, since the European refugee crisis in 2015, this crisis was caused by conflicts that occurred in the Middle East region, especially the Arab Levant region. Refugees seeking protection (asylum seekers) take one way through Turkey before reaching their destination, namely in European countries as refugee recipient countries (Clayton, 2015).

In this paper, the authors see something interesting to discuss. Considering the construction of the Qatar-Turkey natural gas pipeline can become a double-edged knife, especially for the European Union. On the one hand, the EU can reduce its dependence on natural gas supplied from Russia utilizing strengthening its energy security. However, on the one hand, Turkey has assumed new control with its ability to influence energy supply in Europe, which can be a playing card to obtain its national interests and foreign exchange gains.

\section{Realism Theory}

The theory of realism is one of the oldest theories in international relations. This theory has also dominated the international relations discipline, especially after the Second World War. The theory, which has a core at the centrality of the state, has several main principles in viewing the world and international relations, such as maximize the power of a country both against other countries and to defend its national interest, emphasizing national security, having the concept that human nature is evil, as well as the assumption that international 
relations are anarchic. If there is a conflict, these problems resolution will use war (Jackson and Sorensen, 2013).

Realism views that the state has a goal in the form of national interest that can pursue through maximizing power. Power referred to in realism is hard power in the form of efforts to influence other political bodies' behavior or interests through military and economic power (Copeland, 2009). In the realist view, conflict is inevitable, and the best way to avoid war is to strengthen oneself, who is represented by the state. Besides, the state acknowledges it as an entity that acts aggressively because it wants national security interests to pursue and be protected (Mearsheimer, 1995). Then the three fundamental values in realism are; (1) survival, (2) self-help, and (3) stagnancy focus in a separate section. In this paper, the author views that realism's theory is a unified theory used as a case analysis knife. A gas pipeline that connects natural gas production in Qatar to Turkey as a gateway to consumers in Europe will be a tool by Turkey under Erdogan's leadership to influence politics on the blue continent.

The definition of energy security taken from Samantha Olz et al. in the Contribution of Renewables to Energy Security (2007) is "Adequate, affordable, and reliable access to energy fuels and services, it includes availability of resources, decreasing dependence on imports, decreasing pressures on the environment, competition and market efficiency, reliance on indigenous resources that are environmentally clean, and energy services that are affordable and equitably shared." In short, it is a condition when energy sources are affordable in terms of price, and their existence is not disturbed. More deeply, the dimensions of energy security are divided into two, namely; (1) long-term energy security relates to timely investment to supply energy in line with economic development and sustainable environmental needs, and (2) short-term energy security focuses on the ability of the energy system to react quickly to sudden changes in the balance of supply and demand. Energy security is considered necessary considering that human activity is so dependent on energy sources that if one day it is disturbed, it will impact the economic and social sectors. In its dynamic, EU member 
states depend on energy sources in natural gas imported from outside (the majority from Russia). This dependence has made importing countries vulnerable to energy security if the leading exporters stop their exports one day. In this case, the Qatar - Turkey gas pipeline is considered another alternative to diversify natural gas distributors so that the dependencies can also be divided.

\section{DISCUSSION}

\section{Qatar-Turkey initiative in building a Natural Gas Pipeline to Europe}

This section will discuss Qatar and Turkey's initial problems in carrying out or initiating a natural gas pipeline project to Europe. Various internal and external factors pushed the Qatar-Turkey project to build a natural gas pipeline to Europe. The existence of internal and external factors will also be explained to find out the main objective of this project. The internal factor that initiated the construction of a natural gas pipeline to Europe was caused by the bloodshed of more than 400 thousand people due to the Syrian War, which was considered a war over energy resources in the Middle East (Cochrane, 2020). President Bashar al-Assad, who rejected the plan to build a gas pipeline, aims to prevent European energy resources' dependence on Russia from weakening. Also, Syria has a national interest by establishing a "Four Seas Strategy" policy which aims to turn the Syrian state into a gas transit center between the Gulf, Black Sea, Caucasus, and the Mediterranean by utilizing the Euro-Arab Mashreq Gas Pipeline (AGP). However, the AGP project cannot meet domestic demand and export gas to Europe because Egypt does not have enough gas to export. After all, Egyptian gas production has decreased from $220 \mathrm{mcf}$ per day in 2010 to $80 \mathrm{mcf}$ in 2011 (Cochrane, 2020). The AGP project was finally closed in 2012 after a terrorist attack on the Sinai pipeline. To overcome this, a Qatar-Turkey natural gas pipeline to Europe was built to fulfill demand and diversify European gas imports. A consortium made the idea of European and Turkish energy companies in 2002. This project's 
result is that Qatar will achieve more straightforward access to the European market than any Syria pipeline.

Syria's action, which continues to oppose the construction of the QatarTurkey gas pipeline firmly has become a polemic in the regional politics of Arab countries resulting in a rebellion. The insurgency by some groups has been supported by the United States, as evidenced by the US bombing of Syria to overthrow Assad and allow Europe to diversify its dependence on Russia (Cochrane, 2020). Further explains that the external factor in this project is Europe's desire to diversify its dependence on Russia's gas energy resources to create energy security stability in the European region. On the other hand, the construction of a gas pipeline expecting to benefit Turkey as a transit country so that it will have the opportunity to enter into European Union politics, which Turkey has previously tried to apply to join the European Economic Community (ECC), although the membership requirements have not been fulfilled. However, the Qatar-Turkey gas pipeline has given Turkey the role of controlling the energy supply in Europe. One of the Turkish gas pipeline projects is called the Turkstream Gas Pipeline Project. This project is a new gas pipeline system with a maximum capacity of 31.5 bcm per year for two lines, each of which has 15.75 bcm per year; the project is operated from Russia to the Black Sea and across the territory of the Republic of Turkey to the border with the countries-neighboring countries (Republic of Turkey Ministry of Energy and Natural Resources, 2006).

\section{Realist View on the Case Study}

As explained above, the author uses realism theory as a theoretical basis to analyze this case study. The writer will use 2 of 3 realism assumptions, namely survival, and self-help. As we know, Turkey has not been able to become part of the European Union because of the constraining factors and assessment criteria that prevent Turkey from joining the European Union. The factors that cause the European Union refusing Turkey to join the bands firmly are related to the refugee issue. Where the European Union does not want to take the risk of a large number of 
refugees or exodus coming to the European Union who is feared will disrupt the economic stability of the European Union countries. There are differences in culture and political ideology (Gerhards, Jurgen, 2011).

Therefore, in this case Turkey is starting to prioritize its national interests which are manifested by the many plans to be executed behind the construction of the Qatar-Turkey gas pipeline to the European Union, especially to influence the European Union in providing a strategic position and strengthening Turkey's existence. in the political aspect of the European Union (The Irish Times, 2018). Turkey's new dependency on the European Union is a form of survival carried out by Turkey by intensifying steps related to how the Turkish state can strengthen its existence in the European Union region. The concept of survival here is that Turkey must survive and keep its country stable and not experience political, economic, and security shocks. Turkey is optimistic that it will be able to position itself so that it is increasingly needed by European Union countries, namely by the construction of the Qatar-Turkey gas pipeline and the transmission of natural gas supply as an energy source needed to drive all activities in EU countries, especially in the industrial sector.

Through the construction of the Qatar-Turkey gas pipeline, Turkey's position will become increasingly important as an "energy corridor" in the transmission or distribution of abundant oil and natural gas resources from Middle Eastern countries, one of which is Qatar to the Western market, especially the European Union which in fact, they are very dependent on natural gas as their main energy commodity. Continuing the concept of survival, which departs from the realism paradigm, it can be seen that Turkey is implementing this concept by trying to improve the oil and gas pipeline infrastructure to accommodate the increased energy consumption demanded by the Western market, namely the European Union. The goal that Turkey hopes is to be able to regulate the supply of natural gas that will enter the European Union and be able to lead the European Union, especially in its political policy, to consider Turkey to become a member of the 
European Union and have a major influence on the dynamics that occur in the European Union itself. Seeing Turkey's strategic location, which is directly adjacent to the European Union, makes Turkey in a vital position to diversify European supplies related to natural gas through the construction of the Qatar-Turkey gas pipeline (Kilic, 2006).

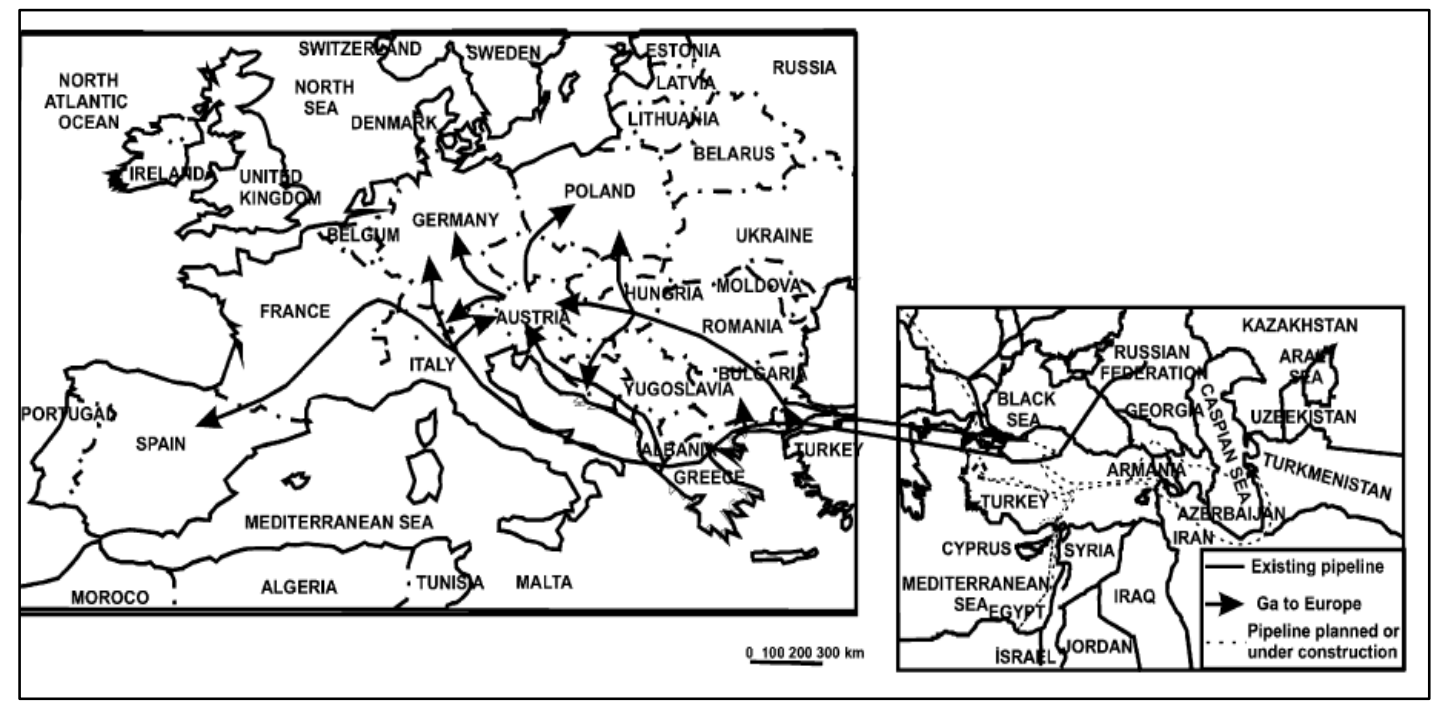

Figure 1. Turkey Gas Pipeline Route to Europe (Republic of Turkey Ministry of Energy and Natural Resources, 2006)

From the figure 1, Turkey is not playing games in carrying out the construction of the gas pipeline project. The gas pipeline construction will later flow natural gas resources to various countries in the European Union such as Germany, Spain, Italy, Poland, Austria, and several other countries. It will have implications for Turkey's existence and position, which is getting more robust in the Middle East region and being the hub country for the Qatar gas pipeline project to the European Union. If analysed more deeply, the author also sees that Turkey applies the concept of self-help, where Turkey under Erdogan's leadership says that Turkey must exist as a country with the capability and is independent of other countries. Turkey wants to prove that with this Qatar-Turkey gas pipeline project, there will no longer be a country that thinks Turkey can survive in this international system because it depends on other countries, especially the European Union. Turkey 
wants to reverse the situation where the European Union can grant certain privileges or strategic positions, especially in the political aspect, to Turkey, because it can reduce its dependence on Russia for natural gas supplies.

It will make it easier for Turkey to carry out cooperation or negotiation processes with EU member countries. Through the concept of self-help, Turkey realizes that with its very strategic geographical location because it is located along an energy-rich area and is passed on to countries with very high levels of energy consumers, it can be used as a political tool capable of lifting Turkey to gain more power from the previous. Suppose Turkey is smart in exploiting the potential and geographical situation given to it, which is said to be the main chain in energy supply, especially oil and natural gas throughout the world. In that case, Turkey will become a developed and enormous country. Moreover, Turkey presenting as "The Bridge Energy between East and West," which makes Turkey's presence very vital in the distribution of energy between energy-rich countries, which incidentally originates from the Middle East to Western countries which tend to strongly encourage industrialization (Kilic, 2006).

It can be concluded that the concepts of survival and self-help that depart from the realism paradigm can be drawn into a case study of the construction of the Qatar-Turkey gas pipeline for the European Union, where Turkey takes advantage of this situation for its political interests in the European Union to gain a strategic position and gain greater power. From before, Turkey also plays a role in the supply of natural gas that will enter the European Union.

\section{Security Challenges in Building the Turkey-Qatar Gas Pipeline}

Erdogan's interest in a US-Turkey cushion zone in Syria will probably forestall Kurdish independence and not battle ISIS. It likewise empowers the structure of the Turkey-Qatar natural gas pipeline proposed in 2009. With the proposed pipeline going through the Aleppo locale-a similar territory for the cushion zone-the Turkey- 
Saudi-Qatar-sponsored Army of Conquest would set up a Sunni Salafist statelet in Syria to empower Ankara, Riyadh, and Doha to partake later on the abundance of the pipeline.

In 2009, Qatar proposed the natura gas pipeline would go through Syria's Aleppo and Turkey into Europe. Be that as it may, Assad hosed this fantasy in 2011 when he rather manufactured an agreement with Iraq and Iran to run an "Islamic pipeline" toward the east to the European market. Presently circumstantially, around the Aleppo locale is additionally where Turkey proposed the US set up the cushion zone to supply "moderate renegade" powers.

On the off chance that Kurds had associated along Turkey's outskirt and shaped a self-sufficient area, plans for the Qatar-Turkey pipeline by means of Saudi Arabia would be entirely devastated. It isn't astonishing that Turkish authorities drew a line from Aleppo to Kobani as a cushion zone, and the US consented to their requests.

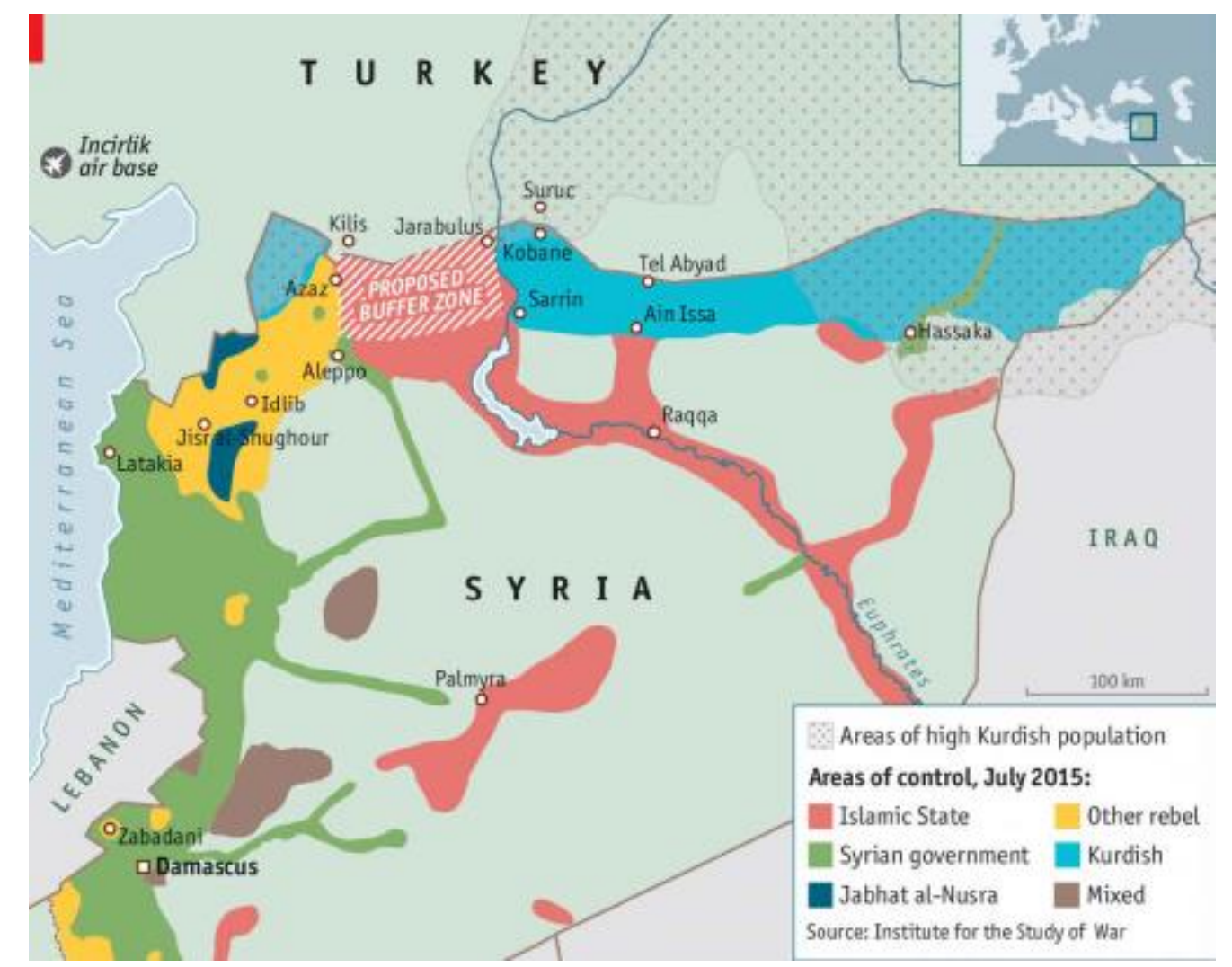

Figure 2. Proposed buffer zone in Syria (The Economist, 2015) 
ISIS likewise profits by the forceful Turkish invasion against PKK-the best boots on the ground battling ISIS. Joined by their shared disdain of the Kurds, Turkey additionally kicked back and watched ISIS pound the YPG in Kobani a year ago.

Writing in Armed Forces Journal, Major Rob Taylor (2014) joined various different intellectuals in seeing that the Syrian common war is a pipeline battle over control of energy supply, with Saudi Arabia, Qatar, and Turkey expecting to eliminate Assad "so they can control Syria and run their own pipeline through Turkey."

"Saudi Arabia and Qatar, just as al Qaeda and different gatherings, are moving to oust Assad and exploit their sought-after Sunni triumph in Damascus. By doing this, they would like to pick up a portion of power over the 'new' Syrian government, and an offer in the pipeline riches." Even on the off chance that it incorporates Turkey clandestinely supporting ISIS against Assad.

In this manner, regardless of whether the Saudi/Qatar/Turkey-upheld Army of Conquest can control barely enough land in Syria for a Salafist statelet to fabricate the Qatar-Turkey pipeline, these Sunni states can at last understand their pipeline dream.

Undoubtedly, the 2012 Defense Intelligence Agency report proves their craving to cut out a Salafist statelet in Syria east of Assad-controlled domain to squeeze his system (In 2012 it was further east, however since Assad has lost a lot of an area it is only east of Latakia).

In gas, the Gas Exporting Countries Forum, with its headquarters in Doha, groups major gas exporters including Iran, Qatar, Russia, Algeria, Egypt, Libya, the UAE, and others. It therefore represents the interests of gas exporters but could again be a venue for considering emergency measures. However, a disruption affecting Russia, for example, would probably not affect Qatar, and vice versa, hence the members can have divergent interests. Some are mainly pipeline exporters and others are more concerned with LNG (Mills, 2016). 


\section{The Future of the Qatar-Turkey Natural Gas Pipeline Project}

It cannot be ruled out that Turkey and Qatar's efforts to be able to build gas pipelines to Europe are very ambitious projects and need special attention from the European Union as the recipient of natural gas supplies. If this project has been successfully implemented in the future, the European Union will benefit from having a supplier of energy sources other than Russia. However, on the other hand, this policy made Turkey strengthen its current position in the Middle East region and impact European dynamics. The uncertainty of Turkey's position in Europe, both geographically and organizationally, requires policies that are quite beneficial for Erdogan's country. Through this project, Turkey felt to have sufficient strength to strengthen its position and impact membership in the European Union organization.

Before going any further on the future of the Turkish and Qatar gas pipelines, there is one thing that needs special attention to support this project's implementation. Namely, the gas pipeline project being carried out by neighboring Qatar, Iran. In this case, Iran is carrying out the same project to help the European Union be less dependent on Russia as its natural gas supplier. These two projects have a significant state role behind them. The Syrian conflict itself also impacted these two projects because the route that had to be passed from the gas pipeline needed to go through Syria. The Qatar-Turkey project is controlled or fully supported by the US. Based on the US's desire, through Obama, to assist Europe in overcoming the problem of dependence on Russia after the Ukraine conflict several years ago. Besides, the US also wants to cut or reduce Russia's influence on the European continent itself. By cutting or reducing the supply of gas sent by Russia, that country's influence will also decrease accordingly.

On the other hand, the Iranian gas pipeline project has the full support of Russia as a permanent gas supplier to Europe. When viewed easily, Iran is much more likely to carry out its gas pipeline project than the gas pipelines run by Turkey and Qatar. This convenience then did not find a bright spot for Iran after the Arab Spring and the civil war in their 
domestic sphere. Even though Qatar first proposed this project in 2009, however, due to the Syrian war factor and US \$ 3 trillion of funding for the Anti-Assad group between 2011 and 2013, Qatar's big obstacle to carrying out this gas pipeline project. It was further hindered after Saudi Arabia was found to have also funded several terrorist groups in the region.

Judging from the obstacles and the presence of other challengers from neighboring countries, it is known that this gas pipeline project will not run smoothly if Syria, through Assad, does not give full permission for the construction of the gas pipeline. Regardless of the big US role in it, if they are unable to meet another route or carry out diplomacy against Assad, then this project itself will fall to Iran and Russia, once again, will regain control of the natural gas market share in Europe, indirectly. Although, in this case, Russia did not ultimately intervene in this project, Iran received strong support and back-up from Russia. So that can be said, the ongoing Iran gas pipeline project will again strengthen Russia in becoming the largest exporter to Europe.

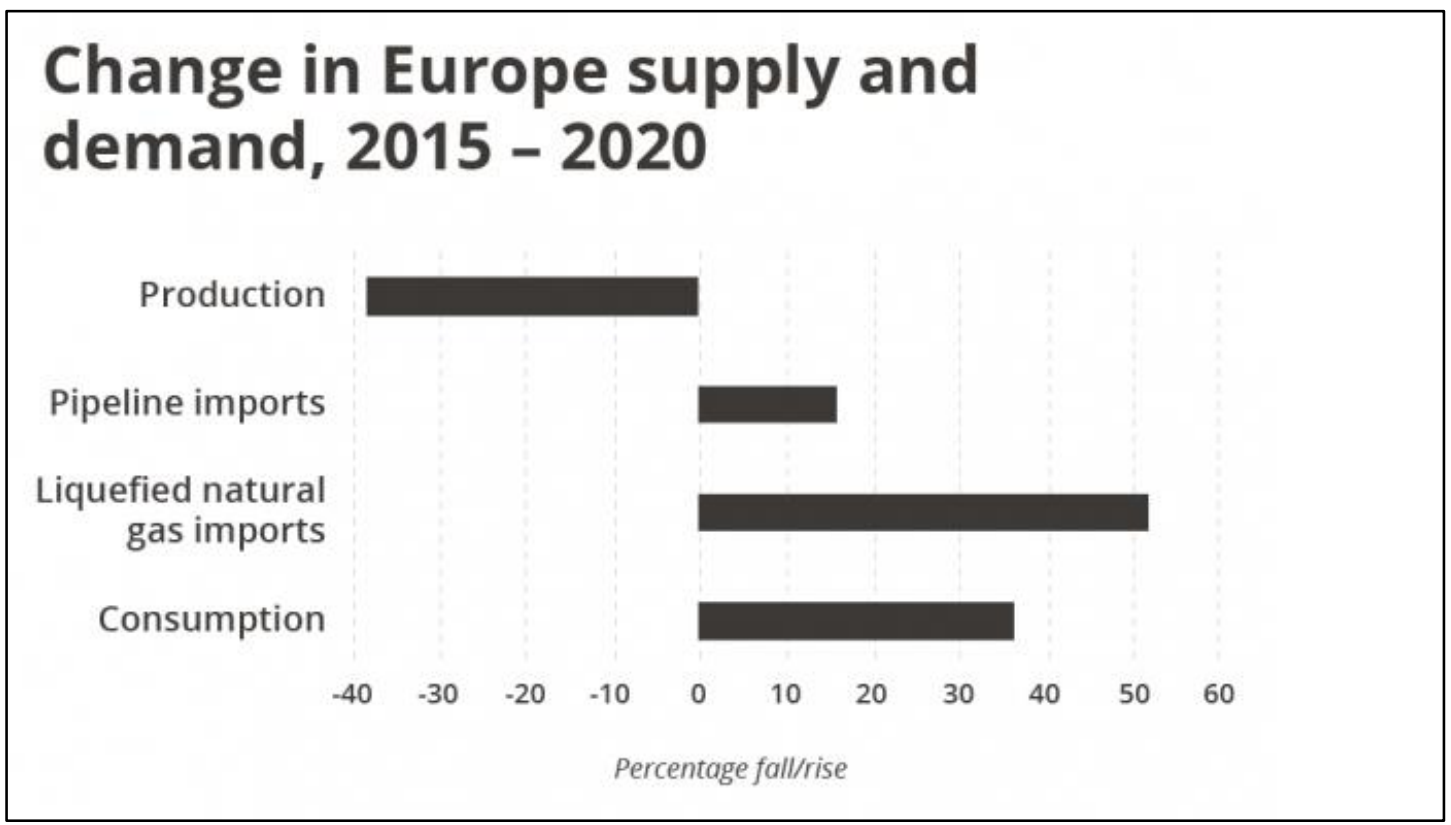

Figure 3. Change in Europe Supply and Demand between 2015-2020 (Cochrane, 2020) 
Referring to figure 3, from the data presented, it was found that between 2015 and 2020, there was a decrease in natural gas production figures by up to $40 \%$ in Europe. Meanwhile, on the other hand, in the same period, consumption actually increased to 35\%. With this situation, countries in Europe, especially members of the European Union, need natural gas imported from outside their territory through important activities using pipeline and shipping logistics facilities.

Judging from the existing data, Europe's dependence on natural gas exported by Russia is quite large. In 2014, Germany imported around $33 \%$ to $60 \%$ of natural gas from Russia. This figure is relatively high, considering that other member countries do not import the same amount. This dependence then becomes the base why Europe wants to continue to look for other suppliers to diversify natural gas energy sources. As previously explained, Qatar will face severe difficulties if it wants to help Europe diversify its natural gas energy sources. Seeing how the figures are shown in 2014 on the level of natural gas supply by Russia will give Qatar even more challenges if this project is to be implemented.

Apart from Qatar, the future of this gas project itself can also be optimized by Turkey to strengthen its position in the Middle East region. Turkey will also have a political impact on the European Union, especially its efforts to become a supranational organization. They will use the logistics route through Turkey to influence EU policy to open the door to their membership system. This means that Turkey also controls the gas supply that will enter the European Union. Indirectly, Turkey is the hub country for natural gas supplies from Qatar to Europe.

The future of the gas pipeline project carried out by Qatar will provide many benefits for all parties involved. It is starting from Qatar, Turkey, the European Union, to the United States. Qatar will become a new supplier to the European Union and reduce Russian exports, which is enough to create dependency on the country led by Putin. Turkey will strengthen its position in the Middle East region and become a hub country for the Qatar gas pipeline project. This will enable Turkey to 
regulate the gas supply that will enter Europe and impact the European Union's political policy in considering Turkey to become a member and provide its dynamics for the supranational organization. The US itself will have an indirect impact through this project because it supports Qatar itself. Also, the US will be successful in reducing Russia's influence through this project. With Russia's reduced gas supply, it will also make it easier for the US to spread its influence in the region. For the European Union itself, they will have a new, unfocused energy source and are likely to reduce their dependence on Russia gradually. However, none would happen without the right solution to persuade Assad to agree to this project because of the path that is followed by the gas pipeline itself. It is felt that proper diplomacy between the countries involved will provide smoothness to Assad's policy of approving the Qatar-Turkey gas pipeline project to Europe.

\section{CONCLUSIONS}

The author concludes that Turkey is taking advantage of the potential and situation of the Qatar-Turkey gas pipeline project to the European Union as a political tool to gain a strategic position and the privilege that Turkey did not get before the planned gas pipeline construction project. The concept of self-help and survival developed by realists can be drawn and reflected in Turkey's current position, which puts forward its national interests to prove that Turkey can survive and is not dependent on other countries, especially the European Union. With this gas pipeline construction project supported by Turkey's very strategic location and directly adjacent to the European Union, it is hoped that it will lead the EU's political policy to place Turkey in another position that is more special than other countries. The author considers the use of this distribution installation to threaten European Union member states' energy security. This scenario is illustrated if Turkey closes the tap of natural gas exports to the European Union, then the fluctuation of energy shortages can occur. 


\section{REFERENCES}

\section{Book}

Copeland, D. (2009). Guerrilla diplomacy: Rethinking international relations. Boulder, CO: Lynne Rienner.

Jackson, R. Dan Sorensen, G. (1995). Pengantar Studi Hubungan Internasional, Teori dan Pendekatan. Yogyakarta: Pustaka Pelajar.

Ölz, S., Sims, R., \& Kirchner, N. (2007). Contribution of Renewables to Energy Security. OECD/IEA.

\section{Journal article}

Pirani, S., \& Gotz, R. (2018). Russian Natural Gas Exports to Europe. Russian Analytical Digest (RAD), 221, 10. doi:https://doi.org/10.3929/ethz-b-000269440

Rosendahl, K. (2018, June). The future of Russian gas exports to the European market [PDF]. Gronigen: Norwegian University of Life Sciences.

Gaub, F. (2014). Gas crisis in Europe and the alternative Qatari role (Rep.).

Gerhards, Jurgen. (2011). Why not Turkey? Attitudes towards Turkish Membership in the EU among Citizens in 27 European Countries. Journal of Common Market Studies.

Kilic, A. M. (2006). Turkey's natural gas necessity, consumption and future perspectives. Turkey: Elsevier

\section{Webpage with an author}

Al Fathi, S. (2017). A tale of two phantom pipelines and Syria. Retrieved 27 November, 2018 from https://gulfnews.com/business/analysis/atale-of-two-phantom-pipelines-and-syria-1.2038040

Chang, C. (2015). Is the fight over a gas pipeline fuelling the world's bloodiest conflict? Retrieved 27 November, 2018 from https://www.news.com.au/world/middle-east/is-the-fight-over-a- 
gas-pipeline-fuelling-the-worlds-bloodiest-conflict/newsstory/74efcba9554c10bd35e28ob63a9afb74

Chang, C. (2015, December 02). The one thing we've all missed in Syrian conflict. Retrieved November 26, 2018, from https://www.news.com.au/world/middle-east/is-the-fight-over-agas-pipeline-fuelling-the-worlds-bloodiest-conflict/newsstory/74efcba9554c10bd35e28ob63a9afb74

Cochrane, P. (2020). The 'Pipelineistan' conspiracy: The war in Syria has never been about gas. Retrieved December 17, 2020, from https://www.middleeasteye.net/essays/pipelineistan-conspiracy-whywar-syria-was-never-about-gas-144022537

McCarthy, N. (2014). Europe is Highly Dependent on Russian Gas. Retrieved $27 \quad$ November, 2018 from https://www.statista.com/chart/2485/europe-is-highly-dependenton-russian-gas/

Mills, R. (2016). Risky routes: Energy transit in the Middle East. Retrieved December 17, 2020, from https://www.brookings.edu/research/risky-routes-energy-transit-inthe-middle-east/

Taylor, R. (2014). Pipeline politics in Syria. Retrieved December 17, 2020, from http://armedforcesjournal.com/pipeline-politics-in-syria/

United Nations. (n.d.). UNHCR chief issues key guidelines for dealing with Europe's refugee crisis. Retrieved from https://www.unhcr.org/55e9793b6.html

\section{Newspaper article}

Al Jazeera. (2017, December 05). Qatar-Gulf crisis: Your questions answered. Retrieved November 26, 2018, Retrieved from https://www.aljazeera.com/indepth/features/2017/o6/qatar-gulfcrisis-questions-answered-170606103033599.html

The Economist. (2015, July 30). Erdogan's dangerous gambit. Retrieved December 18, 2020, from https://www.economist.com /leaders/2015/07/30/erdogans-dangerous-gambit 
The Irish Times. (2017). Turkey's massive gas pipeline a double-edged sword for Europe. Retrieved November 25, 2018 from https://www.irishtimes.com/business/energy-and-resources/turkeys-massive-gas-pipeline-a-double-edged-sword-for-europe-1.3162748

\section{Government publication}

Republic of Turkey Ministry of Energy and Natural Resources. (2006). Natural Gas Pipelines and Projects. Retrieved November 26, 2018, from http://www.enerji.gov.tr/en-US/Pages/Natural-Gas-Pipelines-andProjects

\section{Company and Industry Reports}

British Petroleum Company. (2018). BP Statistical Review of World Energy 2018. London: British Petroleum Co. Retrieved from https://www.bp.com/en/global/corporate/news-and-insights/pressreleases/bp-statistical-review-of-world-energy-2018.html 